\title{
SCENARIO-BASED ELEARNING AND STEM EDUCATION: A QUALITATIVE STUDY EXPLORING THE PERSPECTIVES OF EDUCATORS
}

\author{
Dr. David E. Proudfoot, University of Phoenix, School of Advanced Studies \\ Center for Educational and Instructional Technology Research, Arizona, USA \\ E-mail: dproudfoot@email.phoenix.edu \\ Dr. Mansureh Kebritchi, University of Phoenix, School of Advanced Studies \\ Center for Educational and Instructional Technology Research, Arizona, USA \\ E-mail: Mansureh.Kebritchi@phoenix.edu
}

\author{
A R T I C L E IN F O \\ Original Research \\ Received: December, 23.2016. \\ Revised: February, 03.2017. \\ Accepted: February, 07.2017. \\ doi:10.5937/IJCRSEE1701007P \\ UDK \\ 37.018 .43 \\ 37.041
}

\section{Keywords:}

scenario based learning,

STEM,

student engagement,

eLearning,

motivation.

\begin{abstract}
A B S T R A C T
There are a variety of extra curricular activities and programs that aim to promote Science, Technology, Engineering, and Mathematics (STEM) education, but there are limited examples of extending STEM curriculum by employing scenario-based eLearning opportunities in a mobile lab learning environment. Following students participation in a first of its kind STEM Mobile Lab program that uses a scenario-based eLearning approach for instruction, twelve educators from four Title I elementary schools were asked about their perceptions of the influence of the Mobile Lab program on the STEM education of their students. The semi-structured interview protocol contained questions intended to explore participants' perceptions regarding the influence of a scenario-based eLearning Mobile STEM Lab program on the STEM interest and achievement of students. The study found that a scenario-based eLearning Mobile STEM Lab can influence STEM interest and achievement of elementary students. This promising finding leads to a recommendation for educators to use this approach and similar programs to make students more interested in science and improve their grades. Efforts by educators to design and implement scenario-based eLearning opportunities lead to increased learner engagement.
\end{abstract}

(C) 2017 IJCRSEE. All rights reserved.

\section{INTRODUCTION}

The study of Science, Technology, Engineering, and Mathematics collectively is commonly referred to as STEM education and has become an important topic for researchers because of its role in jobs of the 21 st century. However, rankings of American youth in science, engineering, and math have dropped significantly since the 1970s (National Science Board, 2003; Organisation for Economic Cooperation and Development, 2006). Reflective of the decline, American youth no longer believe the United States leads the way Corresponding Author

Dr. David E. Proudfoot, University of Phoenix, School of Advanced Studies Center for Educational and Instructional Technology Research, Arizona, USA E-mail: dproudfoot@email.phoenix.edu

This work is licensed under a Creative Commons Attribution - NonCommercial - NoDerivs 4.0. The article is published with Open Access at www.ijcrsee.com in invention (The Lemelson-MIT Invention Index, 2011). As the global economic competition gets tougher, American policymakers and researchers are interested in finding ways to increase the number of students pursuing STEM-related majors in order for the United States to continue its role as an economic powerhouse.

National statistics indicate that the next generation is prepared neither for today, nor for future demands (National Research Council [NRC], 2011). For instance, international indicators (e.g., TIMMS and PISA) have shown that U.S. students did not perform well in mathematics and science putting the U.S.'s global leadership in danger. In addition, other studies indicated that there was a decrease in graduation rates in STEM fields (National Science Foundation [NSF], 2010). Those who were trained for STEM-related careers were not sufficient to meet the country's needs (NRC, 2011). Assessment results like these indicate a need to develop STEM content and 
boost individuals' interest towards STEMrelated careers. Lack of student knowledge in STEM and interest in STEM-related careers creates a major constraint for the development of the STEM workforce within the United States of America. There is a need to augment the STEM workforce in a technology-driven society, and create initiatives that develop STEM literacy and boost individuals' interest towards STEM-related professions.

The state of Maryland was the first state to set standards specific to STEM education (Petit, 2012). In April, 2012, the Maryland Board of Education decided to make STEM education a major component in all students' education by stating that the future of the entire nation depended on how schools prepare their students in STEM (Maryland State Department of Education, 2012). Prior to this declaration, several school districts in Maryland implemented initiatives to promote STEM fields to all students. STEM programs including robotics classes and clubs, partnerships with military and engineering organizations, and competitions based on STEM started to develop in the 1990s. Likewise, more schools were offering STEM-focused field trips to expose students to STEM ideas and activities.

As years passed, federal educational accountability policies began to focus more on science and state assessment systems and began to hold schools accountable for student learning in STEM in order to equip students to be college and career ready. The state of Florida enacted several initiatives to improve the quality of STEM education, further engaging students and inspiring future generations of STEM (Manno, 2012). In 2012, the Governor of Florida pushed for statewide education reform that aimed to improve the foundations of STEM education and inspire students to pursue STEM careers. This resulted in STEM fields being promoted through innovations and initiatives, including partnerships with corporate and collegiate sponsors, as well as exposure to new technological programs across the state.

Researchers in STEM education have found several key factors which are important in providing an effective, engaging STEM education. First, "It capitalizes on students' early interests and builds on what they know, and provides opportunities to engage in the practices of science and mathematics to sustain their interests" (STEM Smart, 2014, p. 2). It is important for educators to recognize the challenge of confirming instruction not only covers the most important science and math content, but can engage even bored, distracted, unmotivated students (STEM Smart, 2014). Another report, completed by Hanover Research, stated best practices in elementary STEM programs include "instructional techniques, curriculum and programs, out-of-class activities, the importance of highly-qualified teachers, and longterm program sustainability" (Hanover Research, 2012, p. 10). Some common instructional techniques often used in STEM schools include "traditional teacher-led instruction, project-based learning, workplace or lab-based learning, and the use of technology-supported learning tools" (Hanover Research, 2012, p. 10).

While different educational theories (functionalism, progressivism, reconstructionism, existentialism, cooperative learning) support learning approaches that make learning engaging and meaningful, the scenariobased, e-learning in STEM Mobile Lab program utilizes an experientialism approach to improve student performance. Experientialism is grounded in the idea that experience is the source of knowledge (Dewey, 1938). The STEM Mobile Lab in this study offers students an opportunity to engage with each other and with science content by experiencing an authentic scenario. Students engage in active learning as they process and respond to the scenario using technology-supported learning tools to access curriculum which is described as eLearning. Scenario based eLearning is an effective approach that provides an excellent framework for active learning (Elmore, Mariappan, and Hays, 2003). This approach is based on the understanding that in order for a learner to acquire and retain skills and knowledge, the learner must be placed in a scenario where his/her decisions affect, or alter subsequent events leading to new events.

In order to have a successful integration of STEM education, there are several characteristics that must be implemented (Carnegie Science Center, 2014). A STEM education will be successful when the four major features of STEM education are met. Those four features include STEM being "collaborative, hands-on, problem-solving, and projectbased" (Carnegie Science Center, 2014, p. 15). A collaborative learning approach for students closely resembles the real-world setting which students will encounter in future careers (Carnegie Science Center, 2014).

Described in the context of cognitive and constructivist learning theories, problembased learning is a student centered experiential learning strategy that involves small 
group activities with teachers as facilitators or guides (Barrows, 1996; Gallagher and Gal-lagher, 2013; Grider, 1993; Gijselaers, 1996). While problems become both the focus and stimulus for learning, knowledge is gained through self-directed learning (Honey et al., 2014). Numerous studies support the finding of students in PBL environments are motivated and engaged (Gallaher and Gallagher, 2013). However, literature related to extending the STEM curriculum by employing scenario-based eLearning opportunities in a mobile lab learning environment is limited making research in this field urgent.

A hands-on STEM education offers students a plethora of ways to explore science, technology, engineering, and mathematics. This leads to more student engagement when compared to simply memorizing and taking tests. The problem-solving aspect of STEM education refers to presenting students with a challenge and requiring them to figure out how to solve that particular challenge. Finally, project-based learning involves providing instructions to complete a project (Carnegie Science Center, 2014). Scenario-based eLearning incorporate all four factors to teach science.

This study explores the influence of a scenario-based eLearning mobile lab on STEM education through the eyes of elementary school educators. Scenario-based eLearning is considered as an approach to improve learner engagement and understanding by occupying students in real world learning experiences. Engaging in real world activities are suggested as an effective way of learning by experimental learning theory. Therefore, experiential learning theory is used as a conceptual framework for this study. Emphasis is placed on the perceptions of teachers, instructional designers, and administrators regarding the influence of a scenario-based eLearning STEM mobile lab program on the STEM interest and achievement of fifth grade students.

\section{MATERIALS AND METHODS}

The perceptions of educators in a school district in the Southeast United States of America are explored as a qualitative study of the influence of a scenario-based eLearning Mobile STEM Lab program on the STEM interest and achievement of fifth grade students. A qualitative study allowed for in-depth research, which provided a richer understanding of the participants that is not obvious through quantitative data collection (Merriam, 2009).
The Mobile STEM Lab program was developed and implemented in a school district which educated over 61,000 students with a little less than 20,000 of students attending elementary school during the 2015-2016 school year. The program was offered to fifth grade students throughout the district who attended Title I elementary schools. A school is determined to be a Title I school by high numbers or high percentages of children enrolled from low-income families. The following four questions were used to guide this research:

1. What are instructional leaders and teachers' perspectives regarding the influence of a scenario based eLearning STEM Mobile Lab program on the attitudes and interest in STEM of fifth grade students?

2. What are instructional leaders and teachers' perspectives regarding the influence of a scenario based eLearning STEM Mobile Lab program on the interest of fifth grade students in pursuing STEM-related careers?

3. What are instructional leaders and teachers' perspectives regarding the influence of a scenario based eLearning STEM Mobile Lab program on the achievement of fifth grade students in STEM-related subjects?

4. What are instructional leaders and teachers' perspectives regarding the challenges and implications of implementing a scenario based eLearning STEM Mobile Lab program in the schools?

The participants in this study were elementary school educators from across the school district. The sample consisted of 12 educators who were selected from a population of 5, 213 educators. Educators were selected for the sample through a non-probabilistic, purposive sampling procedure, in which the population was narrowed based on essential attributes. The 12 educators assumed three different types of roles within a school. Eight of the participants were teachers, two of the participants were instructional designers, and two were elementary school administrators. Within the eight teachers, five had less than three years experience teaching STEM courses and three teachers had between three and seven years experience teaching STEM courses to fifth grade students. Both of the instructional designers had between three and five years experience as STEM instructional designers which provide instructional support and resources to support STEM education within the entire school. One of the administrators had less than three years experience as an administrator and another had less than five years experience. All of the participants were as- 
signed to their respective positions during the entire school year. All of the participants were directly involved in the implementation of the Mobile STEM lab program and observed students participating in STEM education lessons before, during and after the implementation of the Mobile STEM Lab program. There were 8 females and 4 males, of average age of 34.4 years. Six of the participants were Caucasian, 1 was African American, 4 were Hispanic, and 1 was Asian.

Within the school district, schools are ranked annually by determining the percentage of the students receiving free and reduced lunch and are given priority to qualify as a Title I school on the basis of the percentage of students from low income families. During the 2015-2016 school year, 17 out of 24 elementary schools across the school district were identified as Title I school which included approximately 2, 214 fifth grade students divided across 138 classes. Of the 17 Title I schools initially identified in the school district, 4 schools agreed to participate in the study. Total enrollment of fifth grade students of the participating schools ranged from 112 students to 182 students per school. All the schools in the study had high percentages of free and reduced lunch students, ranging from $79 \%$ to $93 \%$, with a weighted average of $82.18 \%$ across the schools. Many of the schools had a high percentage of minority students, ranging from $45 \%$ to $89 \%$, with a weighted average of $66.40 \%$ across the schools. The number of English Language Learners also varied widely, ranging from $15 \%-63 \%$, with a weighted average of $24.12 \%$ across the schools. Under the school accountability program of Florida, schools are graded as A, B, C, D, or F based on the academic performance and learning gain measurements of students. Within the 4 schools that participated in the study, one school received a grade of A, one school received a grade of $\mathrm{B}$, and two schools received a grade of C. Forty-one to 53 percent of students meeting or exceeding the benchmark score (passing) on state standardized assessments and/or making learning gains from the previous academic year represents a school grade of $\mathrm{C}$. The percentage range for a school grade of $\mathrm{B}$ is 54 to 61 percent, and the percentage range for a school grade of $A$ is 62 percent or greater. It is hoped that the description of participants' demographics and school types help applying the results of this study into the similar situations with similar demographics.

Mobile STEM Lab program. A school district in the southeast region of the United
States of America has implemented a Mobile STEM Lab that serves as an extension of the STEM curriculum. Among some of the goals for the program, the Mobile STEM Lab aims to enhance fifth graders STEM content knowledge and application through a scenario-based eLearning approach. The innovative Mobile STEM Lab, the first of its kind in the nation for a K-12 school district, aims to connect students to the future by creating engaging and exciting STEM experiences for students by immersing them in authentic scenarios that requires the application of STEM content to solve problems.

The Mobile STEM Lab program was designed as a means for implementing science lessons that are engaging and provide learners with the resources to enhance their performance and overall knowledge. Educational technology is utilized in the mobile lab as instructional tools to enhance the ways that teams of students understand the scenario, gain content STEM content knowledge, interact with each other, and apply STEM knowledge to solve authentic problems. The hope was that as students participated in engaging and positive STEM experiences over time, they would become interested in real life STEM related problems, and ultimately, STEM-related careers. During the 2015-2016 school year, the Mobile STEM Lab spent two to four days at each Title I elementary school to provide the program to all of the fifth grade students at the school. Some schools had 4-5 fifth grade classes while other schools had up to 6 classes which meant that the mobile lab was at that particular school for a longer period of time to accommodate a larger number of classes. Students participated in the STEM Mobile Lab session for 60 minutes.

The Mobile lab consists of a 45-foot motor coach outfitted with seven interactive hands-on student learning stations. Fifth grade students engage in hurricane-themed, standards-based learning. The hurricane scenario was the only scenario offered to students during each session during the first year of the STEM Mobile Lab program. This topic provided an authentic problem for students as hurricanes have the potential to be a natural disaster for students and their communities in this particular geographic area. The session begins with students getting acquainted with the problem as a context for learning while inside the mobile lab. The problem is presented using technological tools such as multimedia and special effects inside the mobile lab to depict that a natural disaster in the form 
of a hurricane has hit the community. Then, students respond to the problem through their critical response teams in different areas of the lab which consist of medical and biological technology and geological, environmental, electrical, structural, and meteorological engineering. All of these teams work together to address the scenario of the hurricane destroying the community.

Working in teams of 4 to 5, students use technological tools to within the mobile lab to gather information and apply it in order to make decisions that can help save and preserve the lives of individuals in the community after the destruction. The content is grounded on STEM-related standards that are implemented an interdisciplinary approach rather than treating the individual subjects as standalone subjects. This type of instructional design approach supports a "coherent and rigorous curriculum" that is crucial for a STEM initiative in any school to be successful. Those in support of STEM education advocate STEM is the "interrelated nature of all the STEM subjects and the necessity of implementing an interdisciplinary approach rather than treating the individual subjects as standalone subjects" (Hanover Research 2012, p. 8).

This paper draws on qualitative data collected by the author through semistructured interviews. The interview protocol contained questions intended to explore participants' perceptions regarding the influence of a scenario-based eLearning Mobile STEM Lab program on the STEM interest and achievement of fifth grade students. After receiving permission from the school district, the qualitative data was collected from three different groups of educators: fifth grade teachers, instructional designers, and administrators. Participants from each of these groups were prompted with a different series of interview questions that were designed to relate to their role and interactions with students within the school. These questions were designed to capture knowledge on the influence of a scenariobased eLearning Mobile STEM Lab on STEM education through the eyes of elementary school educators. Interview questions were developed based upon previous research related to scenario-based learning and experimental learning theory which is used as the conceptual framework of this study.

The author asked several open-ended questions shown in Table 1, Table 2, and Table 3 along with follow-up probes to clarify or learn more about the response of the respondent. Active listening feedback was also provided to gain more indepth understanding and/or to clarify the statements of participants. Participants were invited to describe their perceptions and tell stories of their experiences. Responses to questions were recorded using a Google Voice voicemail feature. After the introduction and the opening script of the interview was shared with the participant, the interviewer conducted a three way call by calling a specific Google Voice phone number and connecting the three calls. Once the call was transmitted, the interviewer waited until the voice mail feature was prompted and then stated the interview question. Following the research question, the participants provided their initial response and any responses to probes or clarifying questions. The dialogue between the interviewer and respondent was captured as a voicemail by Google Voice. As a Google Voice service, each voicemail was recorded and voice transcribed by Google Voice and sent to the interviewer as an email. The accuracy of each transcript was confirmed by the researcher by listening to the audio recording and reviewing the transcription.

A content analysis of the interviews (Miles and Huberman, 1994) was conducted. Interviews were analyzed, beginning with category construction in which participants' responses were analyzed for major themes and ideas (Maxwell, 2013). From these themes, categories were then created to further analyze other interview transcripts. This coding process allowed the researcher to see possibilities for research results. As more interviews and observations were added to the research, some categories became more apparent. It was expected that data would be related to the overarching categories of improved attitudes and interest towards STEM, interest in STEM related careers, increased academic achievement in STEM, and challenges and implications for implementing a scenario-based eLearning Mobile STEM Lab in school districts.

\section{RESULTS}

Attitudes and interest towards STEM. The first research question asked, What are instructional leaders and teachers' perspectives regarding the influence of a scenario based eLearning STEM Mobile Lab program on the attitudes and interest in STEM of fifth grade students? To answer this question, indicators of improved attitudes and interest in STEM were coded. The categories that emerged from the responses of the educators included en- 
gaged and interested which were generated from the most common words used by educators consisting of fun, excited, and energetic. The content analysis revealed that all of the participants had observed improvements in the attitudes and interest towards STEM based on student behaviors. For example, Participant 2 responded, "The scenario-based eLearning experiences allowed for students to be less hesitant to try new things, which helps their attitude because they are more interested in trying science and engineering. The interest level of students is higher and their ability to pick and choose and where they are going in the next phase is new to them." Similarly, Participant 5 revealed improved student interest in STEM through the following statement, "I look at the smiles on the kids' faces and see how happy they are in the program. They like showing me their work; their products. They are excited to show how things work. I remember one student coming up to me with a solution and saying, 'I was thinking about how to solve this issue and then, Ba-ba-boey, it hit me! In order for people to communicate with each other, they need something that will work without electricity so I added pen and paper to my hurricane survival kit.' Students enjoy reporting their ideas and solutions from the scenarios." This comment reflects increases in student interest in STEM and includes students displaying positive emotions which are associated with the scenario-based eLearning experiences.

The content analysis of the participant's responses to the attitudes and interest prompt revealed students being more engaged in learning during STEM and non-STEM courses when scenario-based learning opportunities were integrated in the lesson. For example, Participant 1 responded, "The scenario-based eLearning experience in the Mobile STEM Lab was a very positive experience for students and it has made me realize that they want to do more like this in the rest of the day. When I allow for students to work in teams and problem solve a real life scenario, the instruction is more student centered. Students have a lot of input as to the process or the product of what it is they are doing and learning." Participant 8 stated, "Some of the more hesitant students who normally do not succeed are becoming leaders in the classroom with all the opportunities that scenariobased learning has to offer. Students are more engaged in the lessons due to the hands on and inquiry-based learning." Participant 11 shared, "I have seen students more interested, inquisitive and thinking, thus figuring out the answer for themselves. Some students have begun to engage in research throughout the day in different classes. They research a topic or concept based on a question that they have. I have seen them use different resources for research including non-fictions texts from our classroom library and then sharing what they find with their peers." These statements are evidence of shifts in student engagement and excitement in learning as observable outcomes for improved student attitudes and interests in STEM, and are anticipated to be influenced by scenario-based eLearning.

Interest in STEM-related careers. The second research question asked, What are instructional leaders and teachers' perspectives regarding the influence of a scenario based eLearning STEM Mobile Lab program on the interest of fifth grade students in pursuing STEM-related careers? To answer this question the result of the coding for student STEM-related career interests was examined. The categories that emerged from the responses of the educators included open-minded, chance, and variation which were generated from the most common words used by educators consisting of possibility, thought, change, and idea. The analysis revealed that positive scenario-based eLearning experiences in the Mobile STEM Lab led the participants to perceive shifts in students considering to pursue STEM-related careers. Participant 7 shared, "From talking with students and classroom observations, the experiences with the Mobile STEM lab have "really helped students define, or not define, what they want to be when they grow up. With so much application and handson experiences, students really get a good idea if they want to pursue post secondary degrees and careers in engineering or science." Participant 2 responded, "Each scenario set students up to help their community or solve a real life problem. I believe that students enjoy making positive contributions to their world which helps to think more about a career related to STEM." Participant 12 shared the thoughts of one of the students who experienced the activities in the Mobile STEM Lab by saying, "One student shared that the games opened my eyes to the possibility of a STEM job. I learned that it was not impossible to do stuff like that and it made me like science and math more." Participant 3 shared the thoughts of a student by sharing, "I always thought that I would be an athlete or artist or something like that. I've kinda thought about math and science as just a subject in school." Participant 
responses make apparent that scenario-based eLearning Mobile STEM Lab influenced an improved interest in STEM-related careers of fifth grade students. Many participants described the Mobile STEM Lab experience as a means for expanding student awareness of STEM career opportunities.

Increased academic achievement in STEM. The third research question asked, What are instructional leaders and teachers' perspectives regarding the influence of a scenario based eLearning STEM Mobile Lab program on the achievement of fifth grade students in STEM-related subjects? To answer this question, coding results were examined corresponding to student academic development, particularly identifying responses that describe ways students have displayed classroom behaviors that have the potential to lead to academic success. The categories that emerged from the responses of the educators included thinking, problem solving, and collaboration which were generated from the most common words used by educators consisting of together, interaction, application, and helping. The content analysis to achievement prompt revealed that students academically benefitted from scenario-based eLearning experiences. Participant 9 focused on scenario-based eLearning providing students with opportunities to become problem solvers and critical thinkers. "Besides the higher level of what they are being asked to do, they have to think, not regurgitate information. They have to be creative and apply their knowledge to real world settings." Many participants recognized students interacting with each other in a positive manner. Participant 10 shared, "Working on a specific scenario, students not only engage in active learning, but they are also exposed to group interaction; thus socialization/collaboration becomes an integral part of the learning process." Similarly, Participant 12 responded, "The activities allow for students to communicate orally which helps them to improve their ability to work in teams and interact with other people.

The content analysis of the participant's responses to the achievement prompt revealed students being more responsible for their learning. As Participant 6 stated, "Some students have matured and started to recognize their role as an active learner and group collaborator, and they realize that learning becomes their responsibility. Some students are starting to realize that it is not the teacher's fault if they do not learn something." Participant 1 provided a more sensitive way that they perceived students to be more responsible for their learning by saying, "When you say something to them or provide a limitation to their learning or thinking, their response isn't just compliance or just acceptance, they want to figure out how to solve it and how to change it."

Many teacher participants had responses that were similar to Participant 5, who stated, "After students experienced the scenariobased lesson in the Mobile STEM Lab, they saw the importance of being really good team players and team leaders. They began to understand that they needed to be very good problem solvers, very good critical thinkers, very good at time management, and very good at data and collection and analysis. These are critical skills businesses need and cannot be taught." These perceptions provide evidence that the scenario-based eLearning experience provides opportunities for students to develop leadership and collaborative skills that further prepares them for the workforce and for college.

Challenges and implications for implementing a scenario based eLearning STEM Mobile Lab program. The fourth research question asked, What are instructional leaders and teachers' perspectives regarding the challenges and implications of implementing a scenario based eLearning STEM Mobile Lab program in the schools? To answer this question the result of the coding for challenges and implications for implementing a scenariobased eLearning Mobile STEM Lab in school districts was examined. The categories that emerged from the responses of the educators included hands-on, application, and interactive which were generated from the most common words used by educators consisting of active, technological tools, think, and problem solve. Analysis revealed that scenario-based eLearning Mobile STEM Lab has encouraged students to think about how to solve real life problems through STEM application and has sparked a STEM interest for more students. For example, Participant 7 believes the Mobile STEM Lab was a "huge asset" for encouraging students to be creative with science and math. Continuing on, the participant identified the "hands-on nature of the curriculum" as a strength, as well as the fact that "students get to solve a real-life problem by completing a process from start to finish." Similarly, Participant 9 shared that the Mobile STEM Lab "has helped our STEM instruction to evolve. Because society and the workforce require more technical jobs, we need to expose our students 
to those types of experiences. We need to show our students what they can do with this learning, what the next steps are for them, and what kind of training they can expect in the future. We have to get students interested in these fields." Some of the participants indicated that a scenario-based eLearning approach provided a fun way for students to interact with STEM concepts and they wanted to continue helping students understand how they could make a living and contribute to their community with STEM content.

It does appear that teacher knowledge in STEM provides a challenge for implementing a scenario-based eLearning Mobile STEM Lab program. As Participant 3 stated, "As I reflect on my content knowledge and talk with my colleagues, teachers need help in seeing themselves as STEM capable." Participant 11 shared, "One challenge for me is that I do not recognize that STEM is everywhere." Similarly, Participant 7 stated, "If teachers can better understand the STEM world in which they live, they would better understand the applications of science and math in STEM careers." These responses make apparent that professional development designed to increase STEM content knowledge can assist teachers in connecting the STEM setting with the regular class setting and help them to conceptualize that the STEM mindset is one of a problem-solving mentality.

\section{DISCUSSIONS}

It can be inferred from the content analysis and coding of participant responses that instructional leaders and teachers perceive that a scenario-based eLearning Mobile STEM Lab program can influence the quality of the STEM education for students. Educators interviewed were of like mind regarding the benefits for students, making evident that a scenario-based eLearning Mobile STEM Lab program influenced student achievement and the attitudes and interests of students toward STEM and STEM related careers.

This research study was intended for 8-15 interview participants, which is typical for qualitative studies of this nature. In this qualitative research, interviews provided a first-hand view of the influence that scenario-based eLearning has exerted on improving student achievement and improving the attitudes and interests of students toward STEM and STEM related careers through reflection.

In this study, the perceptions of edu- cators were consistent with each other and all shed a positive light on having students participate in out-of-class activities as a means for cultivating a STEM interest. Also, perceptions connected with the four major features of successful integration of STEM education, as reported by the Carnegie Science Center (2014) which consist of "collaborative, handson, problem-solving, and project-based".

Hom (2014) discussed that STEM education in elementary schools should focus on basic STEM concepts and create an awareness of the STEM field and possible occupations. Chesloff (2013) added by sharing that a highquality STEM learning environment provides students with a structure to build upon their natural disposition to explore, build, and question. A scenario-based eLearning approach to STEM education provides a hands on experience for students to explore and apply STEM concepts to solve a real life problem. This leads to more student engagement when compared to simply memorizing and taking tests (Carnegie Science Center, 2014).

The results of this study confirm that students benefitted from an instructional approach grounded in the experientialism learning theory. A hands-on experience in the Mobile STEM Lab provided students with an active way to explore science, technology, engineering, and mathematics. The results of this study suggest that educators perceived students to be engaged in this type of active learning and influenced the interest of students in STEM. The practical implications of the findings confirmed that as students participated in engaging and positive STEM experiences that they would become interested in STEM and STEM related careers.

There are a variety of extra curricular activities and programs that aim to promote STEM education, but there are limited examples of extending the STEM curriculum by employing scenario-based eLearning opportunity in a mobile lab learning environment. A scenario-based eLearning Mobile STEM Lab requires students to engage with each other and apply STEM content to solve problems that can be found in realistic scenarios. The social implications of this study was related to the need to augment the STEM workforce in a technology-driven society and create initiatives that develop STEM achievement and boost individuals' interest towards STEMrelated professions. Scenario-based eLearning provides educators with the opportunity to create STEM lessons that are fully engaging for the learner and provide them with the 
resources to enhance their performance and their overall knowledge base.

Educators can find value in this qualitative study as the findings reveal that a scenario-based eLearning Mobile STEM Lab can influence STEM interest and achievement of elementary students. This promising finding leads to a recommendation for educators to use this approach and similar programs to make students more interested in science and improve their grades. Efforts by educators to design and implement scenario-based eLearning opportunities lead to increased learner engagement. In particular, students are encouraged to participate more in authentic learning activities that provide positive and engaging STEM experiences which can improve the interests of students toward STEM and STEM related careers.

\section{CONCLUSIONS}

Scenario-based eLearning experiences in a Mobile STEM Lab learning environment have been found to influence student learning related to STEM. Scenario-based eLearning experiences can improve student attitudes, interests, and achievement related to STEM as well as improve interests in STEM-related careers. Further, engaging and positive STEM learning experiences have the potential to improve student attitudes, interests, and achievement towards STEM throughout the instructional day rather than only in STEM classes.

There are a couple of limitations to this study. First, the information the participants provided in reflecting on their experiences was not cross validated by observations of the students. Although different groups of educators were interviewed to gather data from different sources, observations and interviews of the students working in the Mobile STEM lab and in the classroom may provide additional impact for a scenario-based eLearning Mobile STEM Lab on the students. Likewise, the collection of data for this STEM Mobile lab program was conducted after the first year of implementation. As the program continues to be implemented over time, additional quantitative and qualitative data collection may provide additional insight into the impact of scenario-based eLearning experiences in a Mobile STEM Lab learning environment on student learning in order to confirm these initial findings with a larger sample.

Another limitation of the study reported here involves the small and select nature of the population of students under study. This research study was intended for 12-18 interview participants, which is typical for qualitative studies of this nature. However, 12 educators were sampled in a single school district. As the study was conducted in a school district located in the southeast of the United States of America, the participants in this study may act in a way that is normal to those native to the area. Any time research is conducted in one specific area, it is difficult to anticipate how the results could be applied to different situations. It is hoped that the description of participants' demographics and school types help applying the results into the similar situations with similar demographics.

It is notable that the collection of data from instructional leaders and teachers in a wider range of STEM Labs and initiatives that utilize a scenario-based eLearning approach may reveal results. It is encouraged that others studying scenario-based eLearning delivered in Mobile STEM Labs to gather data similar to those that were collected in this study to determine the extent to which other scenario-based eLearning Mobile STEM Labs are influencing student achievement and the attitudes and interests of students toward STEM and STEM related careers. Further, the collection of data from a large number of participants would provide the statistical power necessary to effectively conduct analyses to both quantitative and qualitative data.

\section{ACKNOWLEDGEMENTS}

This research was supported in part by the Center for Educational and Instructional Technology Research at the University of Phoenix as a Research Fellowship. The authors would like to express their gratitude to the school district for the assistance that made this research possible. Thanks are also due to the research participants-all educators: thank you for your participation. Lastly, special thanks are in order to Dr. Joseph Riley and Dr. Christopher Bush for their inspiration and ongoing support for this study.

\section{Conflict of interests}

The authors declare no conflict of inter- 


\section{REFERENCES}

Barrows, H. S. (1996). Problem-based learning in medicine and beyond: A brief overview. In L. Wilkerson \& W. H. Gijselaers (Eds.), Bringing problem-based learning to higher education: Theory and practice (pp. 3-12). San Francisco: JosseyBass. doi:10.1002/t1.37219966804

Carnegie Science Center. (2014). The role of STEM education in improving the tristate region's workforce. Retrieved from http://www.carnegiesciencecenter.org/stemcenter/stemcenterwork-to-do-the-role-of-stem-education/

Chesloff, J. D. (2013). STEM education must start in early childhood. Education Week, 32(23), 27-32. http://maroundtable.com/doc news/1303 EdWeek_STEMEarlyChildhood.pdf

Dewey, J. (1938). Experience and education. New York, NY: Touchstone Books.

Elmore, B., Mariappan, J., \& Hays, G. (2003). Im-proving Performance through Simulation - A Scenario Based Learning Approach. White Pa-per, Experia Solutions.

Gallagher, S. A., \& Gallagher, J. J. (2013). Using Prob-lem-based Learning to Explore Unseen Academ-ic Potential. Interdisciplinary Journal of Problem-Based Learning, 7(1). Available at: http://dx.doi.org/10.7771/1541-5015.1322

Gijselaers, W. H. (1996). Connecting problem based practices with educational theory. In L. Wilkerson \& W. H. Gijselaers (Eds.), Bringing problem-based learning to higher education: Theory and practice (pp. 13-21). San Francisco: JosseyBass. doi:10.1002/tl.37219966805

Grider, C. (1993). Foundations of cognitive theory: A concise review. Retrieved from http://files.eric. ed.gov/fulltext/ED372324.pdf

Gutek, G. L. (1997). Philosophical and ideological perspectives on education (2nd ed.) New York, NY: Prentice-Hall. https://eric. ed.gov/?id=ED419763

Hanover Research. (2012). Best practices in elementary STEM programs. Retrieved from http:// www.hanoverresearch.com/media/Best-Practices-in-Personalized-Learning-Environments.pdf

Hom, E. J. (2014). What is STEM education? Retrieved from http://www.livescience.com/43296-whatis-stem-education.html

Honey, M., Pearson, G., \& Schweingruber, H. (Eds.). (2014). STEM integration in K-12 education: Status, prospects, and an agenda for research. Washington, D.C.: The National Academies Press. http://www.middleweb.com/wp-content/ uploads/2015/01/STEM-Integration-in-K12Education.pdf

Johnson, J. A., Musial, D., Halle, G. E., Gollnick, D. M., \& Dupuis, V. L. (2005). Introduction to the foundations of American education (13th ed.). Boston, MA: Pearson.

Lemelson-MIT Invention Index (2011). Survey reveals potential innovation gap in the U.S.: Young women possess characteristics of inventors, but do not see themselves as inventive. Retrieved from: http://news.mit.edu/2011/lemelson-invention-index

Manno, M. (2012). STEM initiatives in Florida. Retrieved from https://teach.com/blog/stem-flori$\mathrm{da} /$

Maryland State Department of Education. (2012).
Maryland Stem. Baltimore, MD: Maryland State Department of Education.

Maxwell, J. (2013). Qualitative research design: An interactive approach. Los Angeles, CA: Sage Publishing. https://goo.gl/m8XAK6

Merriam, S. (2009). Qualitative research: a guide to design and implementations. San Franscisco: Jossey-Bass.

Miles, Matthew B. \& Huberman, A. Michael (1994). Qualitative data analysis: An expanded sourcebook (2nd ed.). Beverly Hills, CA: Sage. https:// goo.gl/CTfAaq

National Research Council. (2011). Successful K-12 STEM education: Identifying effective approaches in science, technology, engineering, and mathematics. Washington, DC: NAP. https://goo.gl/1JEnUQ

National Science Foundation. (2010). Integrated postsecondary education data system completions survey. Retrieved from https://caspar.nsf.gov/

National Science Board, National Science Founda-tion (2003). The Science and Engineering Workforce. Realizing America's Potential (NSB 0369). Retrieved from https://www.nsf.gov/nsb/ documents/2003/nsb0369/nsb0369.pdf

Organisation for Economic Cooperation and Development (OECD) (2006). Assessing scientific, reading and mathematical literacy. Paris: OECD.

Petit, S. (2012). Maryland moves ahead with STEM initatives. The Baltimore Sun. Retrieved from http://www.baltimoresun.com/ph-ll-cns-stem20121205-story.html

Rowan-Kenyon, H., Swan, A., \& Creager, M. (2012, March). Social cognitive factors, support and engagement: Early adolescents' math interests as precursors to choice of career. The Career De-velopment Quarterly, 60, 2-15. doi:10.1002/ j.2161-0045.2012.00001.x

STEM Smart. (2014). STEM smart brief. Improving STEM curriculum and instruction: Engaging students and raising standards. Retrieved from http://successfulstemeducation.org/resources

Vygotsky, L., \& Kozulin, A. (2011). The dynamics of the schoolchild's mental development in relation to teaching and learning. Journal of Cognitive Education and Psychology, 10(2), 198-211. doi:10.1891/1945-8959.10.2.198 


\section{APPENDIX}

Table 1. Teacher structured interview questions and the alignment to the research questions of the study

\begin{tabular}{lc}
\hline Interview question & $\begin{array}{c}\text { Research } \\
\text { question }\end{array}$ \\
\hline $\begin{array}{l}\text { What have you noticed about the attitudes of students in your class related to } \\
\text { STEM before and after the implementation of the STEM Mobile Lab program? }\end{array}$ & 1 \\
\hline $\begin{array}{l}\text { What have you noticed about the level of interest of students in your class related } \\
\text { to STEM before and after the implementation of the STEM Mobile Lab program? }\end{array}$ & 1 \\
\hline $\begin{array}{l}\text { What did your students like best about the STEM Mobile Lab program? What } \\
\text { evidence have you observed in your classroom to make this conclusion? }\end{array}$ & 1 \\
\hline $\begin{array}{l}\text { How would you describe the career interests of students before participating in a } \\
\text { STEM Mobile Lab session? }\end{array}$ & 2 \\
$\begin{array}{l}\text { What have you noticed about the career interests of students in your class after the } \\
\text { implementation of the STEM Mobile Lab program? }\end{array}$ & 2 \\
$\begin{array}{l}\text { How has the STEM Mobile Lab program changed the achievement level of } \\
\text { students in STEM related subjects? How do you know? }\end{array}$ & 2 \\
\hline $\begin{array}{l}\text { What kind of experience did the STEM Mobile Lab program provide for your } \\
\text { students? }\end{array}$ & 4 \\
\hline
\end{tabular}

Table 2. Instructional designer struc-tured interview questions and the alignment to the research questions of the study

\begin{tabular}{lc}
\hline Interview question & $\begin{array}{c}\text { Research } \\
\text { question }\end{array}$ \\
\hline $\begin{array}{l}\text { What have you noticed about the attitudes of students in your class related to } \\
\text { STEM before and after the implementation of the STEM Mobile Lab program? }\end{array}$ & 1 \\
\hline $\begin{array}{l}\text { What have you noticed about the level of interest of students in your class related } \\
\text { to STEM before and after the implementation of the STEM Mobile Lab program? }\end{array}$ & 1 \\
\hline $\begin{array}{l}\text { What kinds of learning activities in the STEM Mobile Lab do you perceive to be } \\
\text { the most engaging for students? What evidence have you observed to make this } \\
\text { conclusion? }\end{array}$ & 1 \\
$\begin{array}{l}\text { How would you describe the career interests of students before participating in a } \\
\text { STEM Mobile Lab session? }\end{array}$ & 2 \\
$\begin{array}{l}\text { What have you noticed about the career interests of students in your class after the } \\
\text { implementation of the STEM Mobile Lab program? }\end{array}$ & 2 \\
\hline $\begin{array}{l}\text { How has the STEM Mobile Lab program changed the achievement level of } \\
\text { students in STEM related subjects? How do you know? }\end{array}$ & 3 \\
\hline $\begin{array}{l}\text { What (if any) information did you receive from teachers about student } \\
\text { achievement level in STEM related subjects? }\end{array}$ & 3 \\
\hline $\begin{array}{l}\text { How would you describe the learning environment of the STEM Mobile Lab? } \\
\text { What (if any) are the challenges of implementing a STEM Mobile Lab? What } \\
\text { evidence have you observed to make this conclusion? }\end{array}$ & 4 \\
\hline $\begin{array}{l}\text { What (if any) are the implications of implementing a STEM Mobile Lab? What } \\
\text { evidence have you observed to make this conclusion? }\end{array}$ & 4 \\
\hline
\end{tabular}


(IJCRSEE) International Journal of Cognitive Research in Science, Engineering and Education Vol. 5, No.1, 2017.

Table 3. Administrator structured inter-view questions and the alignment to the re-search questions of the study

\begin{tabular}{lc}
\hline $\begin{array}{l}\text { Interview question } \\
\text { Has the STEM Mobile Lab program changed the overall interest level of fifth } \\
\text { grade students in your school about STEM? How do you know? }\end{array}$ & $\begin{array}{c}\text { Research } \\
\text { question }\end{array}$ \\
\hline $\begin{array}{l}\text { What (if any) information did you receive from parents/caretakers about the } \\
\text { attitudes and interests of their children related to STEM before and after the }\end{array}$ & 1 \\
implementation of the STEM Mobile Lab program. & 2 \\
\hline $\begin{array}{l}\text { How would you describe the career interests of students before participating in a } \\
\text { STEM Mobile Lab session? }\end{array}$ & 2 \\
$\begin{array}{l}\text { What have you noticed about the career interests of students in your class after the } \\
\text { implementation of the STEM Mobile Lab program? }\end{array}$ & 2 \\
\hline $\begin{array}{l}\text { Has the STEM Mobile Lab program changed the overall interest level of fifth } \\
\text { grade students in your school about pursuing STEM related careers? How do you } \\
\text { know? }\end{array}$ & 3 \\
\hline $\begin{array}{l}\text { How has the STEM Mobile Lab program changed the achievement level of } \\
\text { students in STEM related subjects? How do you know? }\end{array}$ & 3 \\
$\begin{array}{l}\text { What (if any) information did you receive from teachers about student } \\
\text { achievement level in STEM related subjects? }\end{array}$ & 4 \\
\hline $\begin{array}{l}\text { What (if any) are the challenges of implementing a STEM Mobile Lab? What } \\
\text { evidence have you observed to make this conclusion? }\end{array}$ & 4 \\
\hline $\begin{array}{l}\text { What (if any) are the implications of implementing a STEM Mobile Lab? What } \\
\text { evidence have you observed to make this conclusion? }\end{array}$ \\
$\begin{array}{l}\text { How would you describe the overall school energy/culture when the STEM } \\
\text { description? }\end{array}$ \\
\hline
\end{tabular}

